\title{
Questions to Ask Before Agreeing to Surgery ${ }^{1}$
}

Carolyn Wilken ${ }^{2}$

\section{General Questions}

\section{What is this surgery for? Will it eliminate my problem or slow my condition?}

\section{What other treatment options might I consider?}

\section{What will happen if I don't have this surgery?}

\section{What are the risks of the surgery and what are the success rates?}

\footnotetext{
1 This document is FCS2235, one of a series of the Department of Family, Youth, and Community Sciences, Florida Cooperative Extension Service, Institute of Food and Agricultural Sciences, University of Florida. Original publication date: June, 2005.Visit the EDIS website at http://edis.ifas.ufl.edu

2 Adapted from AARP Health Questions: How to talk to and select physicians, pharmacists, dentists \& vision care specialists Carolyn S. Wilken, Ph.D., M.P.H., Associate Professor, Family, Youth and Community Sciences, IFAS, University of Florida. Reviewed by: Tina Lam, MD, and Mary Harrison, professor, Department of Family, Youth, and Community Sciences, Florida Cooperative Extension Service, Institute of Food and Agricultural Sciences, University of Florida.
}

The Institute of Food and Agricultural Sciences (IFAS) is an Equal Employment Opportunity - Affirmative Action Employer authorized to provide research, educational information and other services only to individuals and institutions that function without regard to race, creed, color, religion, age, disability, sex, sexual orientation, marital status, national origin, political opinions or affiliations. For information on obtaining other extension publications, contact your county Cooperative Extension Service office. Florida Cooperative Extension Service / Institute of Food and Agricultural Sciences / University of Florida / Larry R. Arrington, Dean 
5. Can you do the surgery on an outpatient basis and can I arrange to have appropriate care to recuperate at home instead of the hospital?

6. What kind of help would I need? Who can help me make those arrangements?

7. Can you recommend someone to give me a second opinion?

\section{Financial Questions}

1. Who can answer my questions about the costs of this surgery?

2. What is the cost of the operation and follow-up care? Is it covered by my insurance

3. Will Medicare or my insurance cover those costs? Who can answer my questions about costs?

3. Do I need to clear this with my insurance company or Medicare? 